\title{
Foreign Language Education Standards: Ukrainian Dimension
}

\author{
Alla M. Bogush ${ }^{1, *}$, Tetiana M. Korolova ${ }^{2}$, Oleksandra V. Popova ${ }^{3}$ \\ ${ }^{1}$ Faculty of the Theory and Methods of Preschool Education, South Ukrainian National Pedagogical University named after \\ K. D. Ushynsky, 65020, 26 Staroportofrankivska Str., Odesa, Ukraine \\ ${ }^{2}$ Faculty of Translation, Theoretical and Applied Linguistics, South Ukrainian National Pedagogical University named after \\ K. D. Ushynsky, 65020, 26 Staroportofrankivska Str., Odesa, Ukraine \\ ${ }^{3}$ Foreign Languages Department, South Ukrainian National Pedagogical University named after K. D. Ushynsky, 65020,26 \\ Staroportofrankivska Str., Odesa, Ukraine
}

Received January 21, 2020; Revised February 18, 2020; Accepted February 24, 2020

Copyright $\bigcirc 2020$ by authors, all rights reserved. Authors agree that this article remains permanently open access under the terms of the Creative Commons Attribution License 4.0 International License

\begin{abstract}
Some issues regarding adaptation of the foreign language (English, Chinese) education standards are presented in the article. The purpose of the study is to present all possible correlations related to the foreign language education standards in Ukraine. The relevance of the problem is stipulated by the Ukrainian normative education regulations as well as inter-governmental agreements, which are to be compared and correlated. The appropriate research methods have been considered: theoretical and practical analyses of the normative education documents and methodological prerequisites which could facilitate an adequate correlation of the foreign language education standards in the framework of Ukraine's international cooperation. The common reference levels for foreign language acquisition, the components of foreign and local curricula/ syllabi, the contents of academic mobility programmes and the criteria of teachers' work quality assessment have been presented. The main suggestions (findings) which are to be observed have been given: aspect-targeted training in a foreign language; keeping to local specificities, education requirements and cultural traditions; the need in teachers' advanced training, etc.
\end{abstract}

Keywords Common Reference Levels, Curricula and Syllabi Correlation, Language Education Standards, Assessment Criteria

\section{Introduction}

The issue regarding foreign language education standards and tests is topical and determined by the international ties between Ukraine and different countries of the world. This fact conditions the need in the training of highly qualified specialists who can use professionally their foreign language skills in many spheres of life (social, political, economic, diplomatic, etc.) in order to maintain favourable relations between partner countries. In parallel, the attention is to be paid to the Ukrainian normative educational regulations such as the Laws of Ukraine "On Education", "On Higher Education", the National Strategy for the Development of Education in Ukraine for the period up to 2021 which highlight culture-centricity, preservation and enhancement of national educational traditions, humanization of education and its integration into the world educational space. The evolving international and intercultural relations between both European and Oriental countries and Ukraine prove the necessity to adapt pedagogical technologies in the field of training students majoring in foreign languages (English, Chinese) to the demands of modern inter-governmental collaboration specificities. The designated reasons stipulate the study of the fundamental basis for determining foreign language education-related vectors. Due to the aforementioned, we are going to consider the issues as follows: literature survey; related work which includes general information on teaching / learning foreign languages in Ukraine; common assessment reference for foreign languages; specificities of elaborating common standards for teaching foreign languages in Ukraine (Chinese, in particular); assessment criteria for both quality of teachers' work and students' academic success; teaching problems and suggestions; results and discussions concerning approaches to teaching / learning foreign languages; learning tools (foreign language immersion environment, profession-oriented speech practicing); conclusion. 


\subsection{Normative Education Documents}

It seems to be expedient to analyse the normative education documents related to the foreign language teaching / learning as well as some scholars' reviews related to the designated problem in order to be able to correlate the tasks put forward and to find appropriate suggestions concerning the issues under study.

A significant factor to be taken into consideration is the structure and content of the foreign language competence that encompass the issues as follows: standards on teaching foreign languages and expected education outcomes specified in Common European Framework of Reference for Languages [2], The Ukrainian Laws "On Education" [13] and "On Higher Education" [14], the state standards of the general secondary education and higher education in Ukraine.

One cannot ignore the recommendations initiated by The International Labour Organization which acknowledge the role of creativity as a bases for academic and professional success. It identifies creativity as one of the main skills needed in modern life, and emphasizes the need of the development of creativity as part of its integration into the process of academic education and professional training [9].

According to the above mentioned laws and regulations, one of the principles the State policy of Ukraine is based on is this principle - Ukraine's international integration and integration of Ukraine's education system into European educational and scientific space provided that all the progressive traditions of the national educational and scientific achievements are preserved and developed. In this respect, Ukraine contributes to the correlation of the National Framework of Qualification with the European Framework of Qualification in order to provide for academic and professional mobility and life-long education. Another key point is quality assurance for those who obtain education in Ukraine.

It should be noted that the Chinese "Belt and Road Initiative" and "A New Silk Road" projects have become the most significant ones in international collaboration of many countries, involving Ukraine. Therefore, the key issues on their performance are to be taken into consideration while training Ukrainian students majoring in Chinese (both teaching methods and Translation Studies).

\subsection{Competences and Competencies in Language Education}

The normative approach to teaching / learning foreign languages has induced scholars to perform appropriate research - to write reviews regarding these issues: competencies in education [11]; creative competence [3; 8]; intercultural challenges, intracultural practices [5]; the translation-centred approach to the language acquisition [18]; natural language processing [6]; competence-based approach to teaching foreign languages [4], etc.

S. Rychen and A. Tiana equal skills (learning results) with competencies, they distinguish competency from the notion "competence" which is understood as a complex action system [11]. Y. T. God and H. Zhang deem that language barriers and cultural distance are frequently cited in the literature as factors that hinder communication and investigate how Chinese international students and local students understand and experience intercultural communication [5]. B. Zhu, H. Gao, H. Wu and W. Wang identify the terminological competence as a crucial challenge to non-native speakers of English and highlight the role of a translational approach in developing this competence to tailor particular international standards [18]. $\mathrm{Lu}$ Xiaofei and Chen Berlin associate the significance of learning Chinese as a second foreign language, which is connected with the growth of China's economy and global influence [7].

Ying Tang and Khe Foon Hew examine the usefulness of a mobile instant messaging tool to support the teaching and learning of a foreign language [17]. L. Xiangdong considers instructional objectives to be an important link in the chain of language course design [16]. M. L. Pérez Cañado and D. M. Fernández focus on differences between native and non-native English teachers as well as their didactic behaviour [4]. M. Arias, T. García, Y. Dávila try to find a correspondence between the current global context and the need for an education that responds to the new challenges, a globalized society, where access to knowledge is determined by the understanding of competencies that must be trained at the university [1]. Unfortunately, none of the research has been devoted to the adaptation of local education standards to the European and Oriental standards of teaching / learning foreign languages.

We acknowledge the significance of the creative component in training future specialists of all areas and share the viewpoints of R. Epstein, M. Runco \& R. Albert who associate the creative competence with the ability to effectively demonstrate inventive work, to actualize knowledge and experience under conditions of uncertainty with the aim of solving specific practical problems, readiness for the adaptive use of acquired knowledge, self-education and self-improvement [3].

It is clear from the above that training future teachers and translators / interpreters can be based upon some universal postulates / criteria to assess the foreign language competence (knowledge, skills, abilities). Thus, the way to develop the formulated tasks within the designated purpose is presented in the research.

\subsection{Problem Statement}

The analysis of both theory and practice of the language education in Ukraine has revealed a number of contradictions between: 
1) the demand for highly qualified translators and teachers of foreign languages who are capable to effectively use foreign languages and translation tools on the one hand, and the lack of appropriate innovative training / teaching methods on the other;

2) the international requirements to the content of foreign language proficiency qualifications on the one hand, and the lack of practical implementation of the related methodological support on the other.

\section{Research Goals}

The research goal is to present all possible correlations related to the foreign language education standards in Ukraine.

\section{Research Tasks}

A better understanding of the issue under study involves the following tasks:

1) to give general information on teaching / learning foreign languages in Ukraine; 2) to provide common assessment reference for foreign languages; 3) to present specificities of elaborating common standards for teaching foreign languages in Ukraine (Chinese, in particular); 4) to introduce assessment criteria for both quality of teachers' work and students' academic success; 5) to specify teaching problems and to give corresponding suggestions; 6) to describe some approaches to teaching / learning foreign languages and learning tools.

\section{Research Methods}

Analytical introspection is the right method to analyse the current education-related documents and to the determinants of the academic fundamentals and the holistic language-targeted programmes on the basis of the existing associative links.

The methods of induction / deduction enabled the researchers to analyse and generalise the theoretical bases on the investigated topic, to systemise the results of the study.

It should be stated that the efficiency of the practical outcomes of the initiated study was experimentally proved on the platform of the State institution "South Ukrainian National Pedagogical University named after K D. Ushynsky" in the period of 2017-2019 (academic years). 35 university instructors giving classes in English and Chinese to the students majoring in Translation Studies and Teaching Methods participated in the experiment. 80 students were involved into the experiment.

The purpose of the experiment was to evaluate the quality of teachers' work and students' academic success.
The corresponding criteria were elaborated.

\section{Findings}

\subsection{Proficiency Levels in Language Education}

One of the main tasks which could facilitate the joint effective methodological basis for academic mobility is to elaborate adequate curricular standards in the sphere of teaching English / Chinese as a foreign language. It should be noted that pupils start learning a foreign language on their first year of study having two classes per week at a general secondary school. Preference is given to the English language. Another foreign language (German, French or Chinese) is learned as an optional one, starting, as a rule, from the second year of study. The number of foreign language classes differs depending on a school type and ranges from 2 to 5 classes per week. Nevertheless, school leavers take external independent examinations in the designated languages in order to apply for institutions of higher education. The number of foreign language classes attended at school is not taken into account, for the content of the education standards in foreign languages is the same for all who apply for linguistic specialties.

In Ukraine, we keep to the Common European Framework of Reference for Languages: Learning, Teaching, Assessment [2]. There exist six proficiency levels:

- Breakthrough, corresponding to what Wilkins in his 1978 proposal labelled 'Formulaic Proficiency', and Trim in the same publication 1 'Introductory'.

- Waystage, reflecting the Council of Europe content specification.

- Threshold, reflecting the Council of Europe content specification.

- Vantage, reflecting the third Council of Europe content specification, a level described as 'Limited Operational Proficiency' by Wilkins, and 'adequate response to situations normally encountered' by Trim.

- Effective Operational Proficiency which was called 'Effective Proficiency' by Trim, 'Adequate Operational Proficiency' by Wilkins, and represents an advanced level of competence suitable for more complex work and study tasks.

- Mastery (Trim: 'comprehensive mastery'; Wilkins: 'Comprehensive Operational Proficiency'), corresponds to the top examination objective in the scheme adopted by ALTE (Association of Language Testers in Europe). It could be extended to include the more developed intercultural competence above that level which is achieved by many language professionals. 


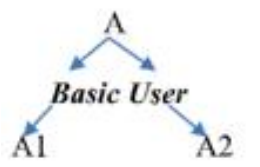

(Break (Waystage) through)

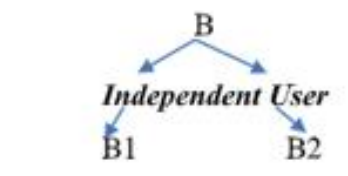

(Threshold)

(Vantage)

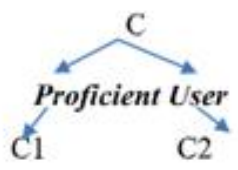

(Effective

(Mastery)

Operational

Proficiency)

Figure 1. Proficiency levels

In Ukraine, by the end of a Bachelor course an undergraduate student is to pass the HSK 4 exam which corresponds to the level B2 (independent user).

In China, the Chinese Proficiency Test HSK (汉语水平 考试 The Hanyu Shuiping Kaoshi) also covers six levels, their gradation seem to coincide. The most general reference levels for any foreign language are called: elementary, intermediate and advanced.

Students are trained in these kinds of language learning activities: listening comprehension, reading, speaking (spoken interaction - dialogic speech, spoken production - monologic speech) and writing. A particular attention is paid to the use of language (lexical and grammatical aspects) and translation.

As for foreign students (non-speakers) who study Chinese, they are presupposed to be supplied with high-quality curricula according to that they are also trained in calligraphy, playing musical instruments, martial arts, history, etc.

It should be mentioned that Harbin engineering university (HEU) is our partner university which receives Ukrainian students within the programmes of academic mobility. The HEU Administration board is guided by the principle of open education and creates favourable pedagogical conditions for exchange students: oversea students'-oriented curricula in the Chinese language and culture, joyful atmosphere for study, natural immersion into the study and communication with Chinese teachers and native speakers aligned with foreign students' capacities and skills.

Confucius Institute at South Ukrainian National Pedagogical University named after K. D. Ushynsky closely collaborates with Harbin Engineering University in terms of elaborating common standards for teaching Chinese in Ukraine. We are guided by the Chinese language syllabi developed by our Chinese colleagues in HEU who teach Chinese to our exchange students in China. Thus, the CI team together with the Ukrainian academic staff adapt the Chinese language standards in these vectors:

- teaching Chinese at general secondary schools;

- teaching the Chinese language and Literature to the students majoring in Secondary education (the Chinese language and Literature);

- teaching Chinese as a First Foreign language to the students - future translators / interpreters;
-

teaching Chinese as a Second Foreign language to the students - future translators / interpreters;

- teaching theoretical and practical aspects of translating / interpreting from Chinese into English to the students majoring in Translation Studies;

- teaching Chinese to the students majoring in non-philological specialties.

The content of the syllabi and didactic materials are transformed into certain planes depending on students' specialties.

A. Secondary education (the Chinese language and Literature). We study secondary school curricula and syllabi, then analyse the university ones in order to correlate the education components.

B. Translation Studies. The profession-oriented courses are built in accordance with modern demands. They are predetermined by discourse specificities and functional styles (belles-lettres, official / business, publicistic / sociopolitical, scientific and technical), on the one hand; and by working modes like interpreting (simultaneous, consecutive) and translating (including sight translating); computer-aided translation, machine-aided human translation (MAHT) or interactive translating, etc., on the other hand.

C. Non-philological specialties and / or linguocultural courses. The syllabi content usually corresponds to the requirements of a particular level determined by the HSK.

The curricula and syllabi are discussed with the Chinese partner-university and renewed in compliance with current situations. Nowadays, there are Chinese language curricula for Bachelor, Master and Post-graduate courses (both for full-time and part-time students) and for extra-class multilevel courses.

When Ukrainian students are sent to our Chinese partner-university as exchange students within the CI academic mobility programmes, we arrange all necessary documentation and adapt the names of disciplines, tutorial hours and forms of control proposed by our Chinese colleagues to the Ukrainian education standards. It should be noted that the Chinese syllabi intended for the exchange students differ from those ones aimed at students who major in Chinese since Ukrainian students usually join one-term (320 contact hours) or one-academic-year programmes (704 contact hours) and 
they are trained in similar linguistic aspects depending on their proficiency level according to the HSK:

- "Chinese Speaking Course", "Chinese: Listening Comprehension”, “Complex Chinese: Lexical Units, Grammar, Writing, Phonetics" (for one-term programmes);

- "Chinese Speaking Course", "Chinese: Listening Comprehension", “Complex Chinese: Lexical Units, Grammar, Writing, Phonetics", "Chinese: Reading" (for one-year-academic programmes).

We encounter some inconveniences while equating the disciplines:

1. Differences in the quantity of academic (contact) hours, preparation hours and credit hours. In Ukraine, one credit hour is assigned for 10 contact hours (theoretical or practical classes, seminars) and 20 preparation hours (self-guided / independent work).

2. Differences in curricula and syllabi of the specialties "Secondary education (the Chinese language and Literature)" and "Philology. Translation Studies", which causes significant ranging while re-crediting the disciplines taught in China within the programmes of academic mobility.

The translation syllabi contain these profession-oriented disciplines: "First Foreign Language (English / Chinese)", "Second Foreign Language (English / Chinese)", "Theory and Practice of Translation", "Discourse Studies". Thus, we can re-credit only two of them: "First Foreign Language (Chinese)" or "Second Foreign Language (Chinese)". We negotiated the HEU office of international education and our students were proposed to take optional courses related to the Chinese teaching methods or specific linguistic aspects.

The Chinese language and Literature syllabi include these profession-oriented disciplines: "Oral and Written Practice (Chinese)", "Practical Phonetics (Chinese)", "Practical Grammar (Chinese)", "Theoretical Phonetics (Chinese)", "Chinese Teaching Methods". We combine disciplines in order to find correlations with the Chinese syllabi.

To maximally equate the Chinese and Ukrainian curricula and syllabi, the CI staff regularly prepare written reports, elaborate didactic material (tests and other assignments) for Ukrainian students, organize numerous Chinese classes (basic Chinese, Chinese etymology, Tai Chi Chuan classes, HSK classes, etc.) and cultural events, select corresponding textbooks.

\subsection{Assessment Criteria for the Quality of Teachers' Work}

Assessment criteria. Another important issue to be acknowledged is assessment standards - for both quality of teachers' work and students' academic success - which comply with current situations, innovations and social demands. The CI senior teaching staff, co-directors and Ukrainian Professors adapt the Chinese requirements to education results to the European ones. Accordingly, Ukrainian students must demonstrate certain knowledge, skills and abilities after mastering a definite language proficiency level.

Let us stop at the assessment criteria for the CI teachers' proficiency which the CI initiative group has developed (see table 1).

Table 1. The assessment criteria for the CI teachers' proficiency

\begin{tabular}{|c|c|c|}
\hline Criterion & $\begin{array}{l}\text { Criterion } \\
\text { components }\end{array}$ & Specification, scores \\
\hline \multirow{3}{*}{$\begin{array}{l}\text { Attitude } \\
\text { to work }\end{array}$} & Initiative & $\begin{array}{l}\text { - manifestation of an initiative to work, which contributes to the disclosure of teacher's } \\
\text { creative abilities and potential (9-10); } \\
\text { an initiative to work is in line with the norm within the assigned tasks }(7-8) \text {; } \\
\text { a low level of manifestation of an initiative to work, which prevents the effective } \\
\text { implementation of the necessary tasks (5-6); } \\
\text { no initiative to work is demonstrated, which impedes the fulfilment of the necessary tasks } \\
\text { (1-4). }\end{array}$ \\
\hline & $\begin{array}{l}\text { Organizational } \\
\text { abilities }\end{array}$ & $\begin{array}{l}\text { - } \quad \text { personal behaviour is determined by teacher's high moral qualities }(9-10) \text {; } \\
\text { personal behaviour complies with moral and ethical standards. Can comply with all the } \\
\text { Confucius Institute requirements }(7-8) \text {; } \\
\text { - } \quad \text { personal behaviour partially complies with moral and ethical standards. Partially complies } \\
\text { with the Confucius Institute requirements }(5-6) \text {; } \\
\text { - has difficulty complying with the Confucius Institute rules }(1-4) \text {. }\end{array}$ \\
\hline & $\begin{array}{l}\text { Commitment } \\
\text { work }\end{array}$ & 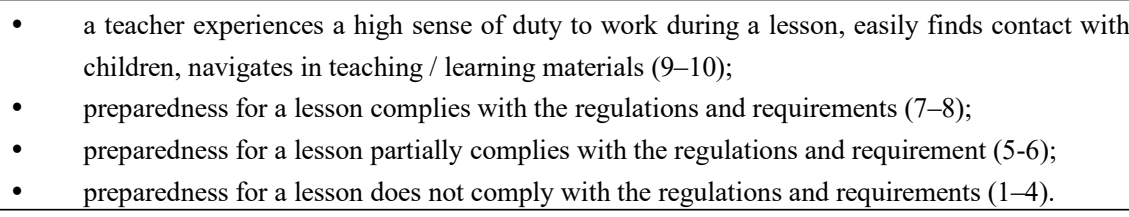 \\
\hline $\begin{array}{l}\text { Quality } \\
\text { of work }\end{array}$ & $\begin{array}{l}\text { The amount of } \\
\text { work fulfilled } \\
\text { during a lesson }\end{array}$ & $\begin{array}{l}\text { - a high level of academic load; there are exercises for all types of speech activities: listening } \\
\text { comprehension, speaking, reading, writing }(9-10) \text {; }\end{array}$ \\
\hline
\end{tabular}




\begin{tabular}{|c|c|}
\hline & $\begin{array}{l}\text { - a sufficient level of academic load; there are exercises for all types of speech activities: } \\
\text { listening comprehension, speaking, reading, writing (7-8); } \\
\text { an insufficient level of academic load; exercises do not cover all types of speech activities } \\
\text { (5-6); } \\
\text { - a low level of academic load; exercises cover one type of speech activity (1-4). }\end{array}$ \\
\hline Work efficiency & $\begin{array}{l}\text { - a high level of teaching proficiency; keeping to the normative structure of the lesson to the } \\
\text { full: an introductory part, homework checking, explanation of a new topic and its mastering, } \\
\text { the availability of appropriate training methods (projects, games, profession-oriented tasks, } \\
\text { etc.), summing up (summarizing outcomes of a lesson, assessment of students' class } \\
\text { activities, homework explanation); a teacher keeps to the time limits (9-10); } \\
\text { teaching proficiency complies with qualification standards, the efficiency of teaching is } \\
\text { confirmed by the training results; the normative structure of the lesson is not fully observed, } \\
1-2 \text { points of the normative structure components of the lesson are missing; a teacher keeps } \\
\text { to the time limits (7-8); } \\
\text { an insufficient level of teaching proficiency; the normative structure of the lesson is not fully } \\
\text { observed: } 2-3 \text { points of the normative structure components of the lesson are missing; a } \\
\text { teacher does not have time to give homework and evaluate students' class activities during } \\
\text { the lesson (5-6); } \\
\text { a low level of teaching proficiency; there are no markers of teaching effectiveness; the } \\
\text { normative structure of the lesson is not observed: most of the points in the normative } \\
\text { structure of the lesson are missing; a teacher does not have time to give homework and } \\
\text { evaluate students' class activities during the lesson (1-4). }\end{array}$ \\
\hline Didactic material & $\begin{array}{l}\text { - appropriate use of didactic material and ICT }(9-10) \text {; } \\
\text { most exercises and presentation of educational material are accompanied by the use of } \\
\text { didactic material and ICT (7-8); } \\
\text { - } \quad \text { artial use of didactic material and ICT }(5-6) \text {; } \\
\text { complete lack of didactic material and ICT }(1-4) \text {. }\end{array}$ \\
\hline
\end{tabular}

Teaching problems. It is significant that Chinese teachers and volunteers improve the designated personal qualities and proficiency skills to avoid the gaps as listed below:

1. Teachers demonstrate lack of experience; teaching methods do not comply with schoolchildren's / higher school students' education levels.

2. Teachers make grammar mistakes.

3. There is a lack of understanding from the side of schoolchildren / higher school students because a teacher does not know a local language.

4. Teachers demonstrate ignorance of syllabus contents and / or students' proficiency levels.

5. Teachers neither observe no correct students' mistakes, which can lead to further complicated linguistic problems.

6. Teachers are not familiar with age-oriented teaching methods.

\subsection{Assessment Criteria for the Quality of Students' Academic Success}

Based on the educational practice in teaching foreign languages, we have elaborated a unified complex of knowledge, skills and abilities that constitute the linguistic-and-communicative competence of our students in foreign languages (English and Chinese). We were guided by these research issues: foreign language immersion environment [12]; the use of information and communication technologies in the process of teaching foreign languages [15]; competence-based approach to teaching foreign languages; profession-oriented speech practicing. The competence-based approach allowed us to specify the key competencies-components in listening comprehension, speaking, reading and writing. Let us observe them (see tables 2-7). 
Table 2. The linguistic-and-communicative competence in foreign languages (English, Chinese): Listening comprehension

\begin{tabular}{|c|c|c|}
\hline Knowledge & Abilities & Skills \\
\hline \multicolumn{3}{|c|}{ Listening comprehension } \\
\hline $\begin{array}{l}\text { - phonetic knowledge of the } \\
\text { peculiarities of the tone system } \\
\text { in Chinese, the prosodic } \\
\text { systems of the studied foreign } \\
\text { languages alongside with the } \\
\text { intonation-syntactic structures } \\
\text { of utterances representing } \\
\text { different communicative } \\
\text { types; regularities of } \\
\text { intonation within the studied } \\
\text { foreign languages; } \\
\text { intonational and structural } \\
\text { markers of syntax boundaries, } \\
\text { phrases; communicative } \\
\text { functions of interjections and } \\
\text { functional words; knowledge } \\
\text { of the transcription rules and } \\
\text { speech intonation; } \\
\text { phonostylistic awareness. }\end{array}$ & $\begin{array}{l}\text { - phonetic abilities to identify sound } \\
\text { compositions in the foreign languages } \\
\text { under study (including tone markers in } \\
\text { Chinese) in isolation and in speech } \\
\text { continuum; to distinguish main and } \\
\text { auxiliary lexical units, elements of } \\
\text { communication and structure-forming } \\
\text { components; to perceive syntagmatic } \\
\text { boundaries; to determine a } \\
\text { communicative type of an utterance; } \\
\text { abilities to develop authentic oral speech } \\
\text { in the form of a dialogue / monologue / } \\
\text { polylogue; } \\
\text { abilities to decode intonation of audio } \\
\text { texts representing different genres and } \\
\text { styles; } \\
\text { abilities to adequately perceive by ear } \\
\text { numerals, foreign and native proper } \\
\text { names, phraseologisms / idioms, 成语 / } \\
\text { chéngyǔ (in Chinese), colloquial lexical } \\
\text { units. }\end{array}$ & $\begin{array}{l}\text { - skills to decode interlocutors' } \\
\text { communicative intention (regardless of } \\
\text { their age, social status, gender); } \\
\text { skills to distinguish the main idea and } \\
\text { adequately perceive meaningful details of } \\
\text { a message (within the academic and } \\
\text { professional environment) by keywords } \\
\text { and radicals (in Chinese); } \\
\text { skills to understand basic ideas, general } \\
\text { content and details in the course of } \\
\text { listening to dialogues, monologues and } \\
\text { polylogues when dealing with a } \\
\text { multi-genre audio material (debates, } \\
\text { official reports, telephone conversations, } \\
\text { radio and television broadcasts, etc.); } \\
\text { skills to keep in memory the perceived } \\
\text { information; } \\
\text { skills to fix in writing interpreter's } \\
\text { transcripts that could facilitate the } \\
\text { reproduction of the heard information. }\end{array}$ \\
\hline
\end{tabular}

Table 3. The linguistic and communicative competence in foreign languages (English, Chinese): Integrative speaking skills

\begin{tabular}{|c|c|c|}
\hline Knowledge & Abilities & Skills \\
\hline \multicolumn{3}{|c|}{ Integrative complex of knowledge, skills and abilities in speaking } \\
\hline $\begin{array}{l}\text { - fundamental knowledge of practical } \\
\text { phonetics (English, Chinese, native } \\
\text { language); } \\
\text { of normative theoretical and practical } \\
\text { grammar; communicative grammar } \\
\text { (English, Chinese, native language); } \\
\text { knowledge of lexical minimum and } \\
\text { phraseology (English, native language), 成 } \\
\text { - 语 / chéngyǔ (in Chinese); } \\
\text { knowledge of linguistic means of expressing } \\
\text { modality; communicative variations at the } \\
\text { suprasegmental level; linguistic and } \\
\text { structural features of prepared / spontaneous } \\
\text { dialogic / monologic speech (English, } \\
\text { Chinese, native language); } \\
\text { knowledge of the communicative functions } \\
\text { of exclamations; } \\
\text { knowledge of psycholinguistic patterns of } \\
\text { text / discourse generation; } \\
\text { knowledge of the logical and syntactic } \\
\text { structure of utterances representing different } \\
\text { communicative types (English, Chinese, } \\
\text { native language); } \\
\text { awareness of the "aesthetic culture" in a } \\
\text { world-wide format; } \\
\text { awareness of speech etiquette. }\end{array}$ & 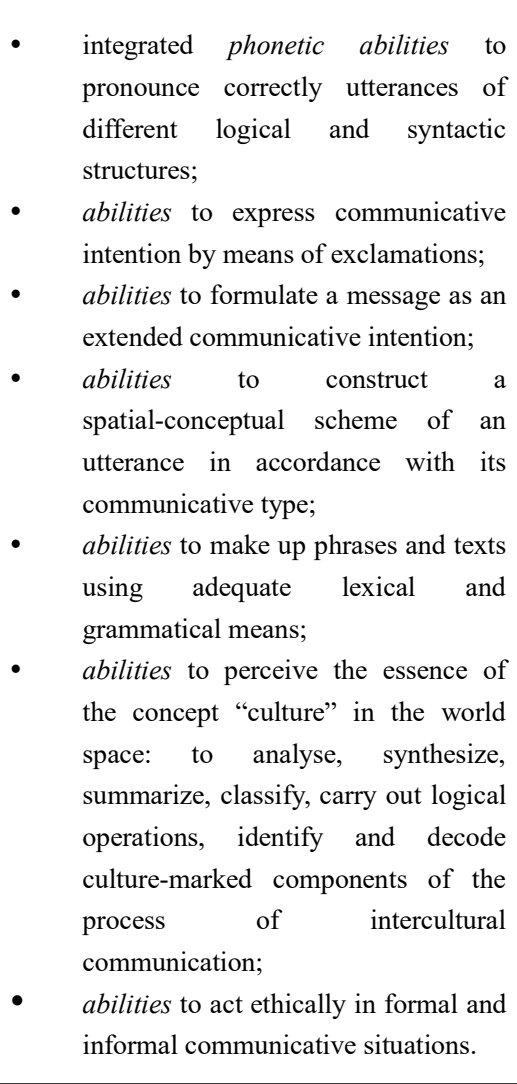 & $\begin{array}{l}\text { - skills to perform inner } \\
\text { programming, to construct } \\
\text { spatial-conceptual schemes for } \\
\text { generating utterances; } \\
\text { - skills to use oratory techniques; } \\
\text { skills to act creatively, } \\
\text { deliberately and aesthetically } \\
\text { towards the representatives of } \\
\text { other cultures on the basis of } \\
\text { "mentally processed" } \\
\text { information regarding the } \\
\text { culture-marked components of } \\
\text { the process of intercultural } \\
\text { communication; } \\
\text { skills to choose and apply an } \\
\text { adequate model of speech } \\
\text { behaviour in typical } \\
\text { communication situations (when } \\
\text { interacting with the English and } \\
\text { Chinese native speakers). }\end{array}$ \\
\hline
\end{tabular}


The listening comprehension skills help learners to master speaking skills in foreign languages both being isolated from native speakers-teachers and involved into teaching / learning process with native speakers. We have distinguished an integrative complex of knowledge, skills and abilities that learners are to demonstrate in their interaction with native speakers (see table 3 ).

Furthermore, some particular knowledge, skills and abilities in monologic and dialogic speech have been specified in terms of learners' immersion into foreign language environment (see tables 4-5). It should be mentioned that while participating in the programmes of academic mobility, it takes learners less time to master speaking starting from interaction with native speakers in a foreign language (dialogic skills) since students have an opportunity to solve everyday needs by means of natural communication.

Table 4. The linguistic and communicative competence in foreign languages (English, Chinese): Dialogic speech

\begin{tabular}{|c|c|c|}
\hline Knowledge & Abilities & Skills \\
\hline \multicolumn{3}{|c|}{ Dialogic speech } \\
\hline $\begin{array}{l}\text { integrative knowledge of functional } \\
\text { classification of dialogues, } \\
\text { composition and linguistic } \\
\text { framework of dialogues } \\
\text { (dialogue-proposal, } \\
\text { dialogue-questioning, } \\
\text { dialogue-motivation to acting, } \\
\text { dialogue-exchange of thoughts, } \\
\text { interviews, etc.); } \\
\text { integrative knowledge of telephone } \\
\text { conversations (formal and informal) } \\
\text { on a variety of topics; } \\
\text { awareness of people's } \\
\text { co-functioning in socially } \\
\text { heterogeneous groups as well as of } \\
\text { interaction of representatives of } \\
\text { different cultures (English, Chinese, } \\
\text { Ukrainian) in a multicultural } \\
\text { environment. }\end{array}$ & 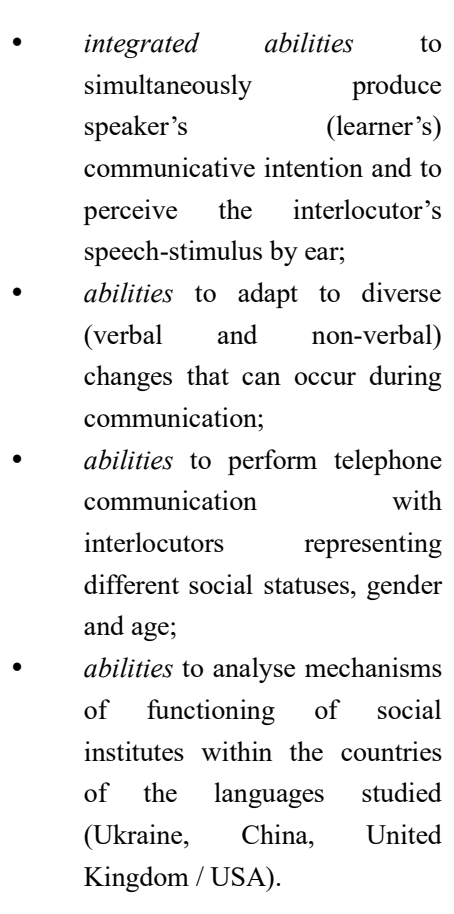 & $\begin{array}{l}\text { - skills to respond adequately to the } \\
\text { statement-stimulus in the form of a brief } \\
\text { response expressing learner's own } \\
\text { communicative intention and to formulate } \\
\text { an appropriate message; } \\
\text { skills to spontaneously participate in } \\
\text { dialogues and polylologues (discussions, } \\
\text { seminars, conferences, disputes, official } \\
\text { negotiations, etc.); } \\
\text { skills to initiate communication and to } \\
\text { maintain it; } \\
\text { skills to adequately understand and } \\
\text { respond to the responses and suggestions } \\
\text { of interlocutors (despite possible technical } \\
\text { obstacles - noises, communication } \\
\text { disconnection, etc.); } \\
\text { skills to design and implement a strategy } \\
\text { of one's life in harmony with the interests } \\
\text { and needs of different social groups, } \\
\text { individuals, in accordance with social } \\
\text { norms and rules of the countries } \\
\text { concerned. }\end{array}$ \\
\hline
\end{tabular}

Thus, having strong interaction skills, learners seem to have enough background to develop further monologic speaking skills (especially within foreign language immersion).

Table 5. The linguistic and communicative competence in foreign languages (English, Chinese): Monologic speech

\begin{tabular}{|c|c|c|}
\hline Knowledge & Abilities & Skills \\
\hline \multicolumn{3}{|c|}{ Monologic speech } \\
\hline 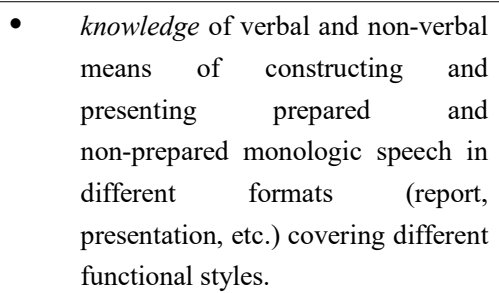 & $\begin{array}{l}\text { abilities to present public } \\
\text { speaking on various topics; } \\
\text { abilities to make up } \\
\text { spontaneous monologues } \\
\text { on diverse topics. }\end{array}$ & $\begin{array}{l}\text { skills to produce lucid detailed prepared } \\
\text { monologues on a wide range of diverse topics } \\
\text { and present them in different formats; } \\
\text { skills to produce spontaneous monologues on a } \\
\text { wide range of diverse topics and present them } \\
\text { in different formats. }\end{array}$ \\
\hline
\end{tabular}


Table 6. The linguistic and communicative competence in foreign languages (English, Chinese): Reading

\begin{tabular}{|c|c|c|}
\hline ledge & Abilities & Skills \\
\hline \multicolumn{3}{|c|}{ Reading } \\
\hline $\begin{array}{l}\text { - awareness of the peculiarities of different } \\
\text { reading types (skimming, scanning, } \\
\text { in-depth reading) and forms of reading } \\
\text { (aloud and silent); } \\
\text { - knowledge of text structures: character } \\
\text { and word recognition (English); radical } \\
\text { and Chinese character } \\
\text { (hieroglyph-symbol) recognition (font: } \\
\text { cursive and print); space between words } \\
\text { and (sub)paragraphs (English); space } \\
\text { between word combinations / clauses / } \\
\text { sentences and (sub)paragraphs (Chinese); } \\
\text { non-linguistic units (numerals, figures, } \\
\text { units of measuring, formulae, equations, } \\
\text { etc.) }\end{array}$ & 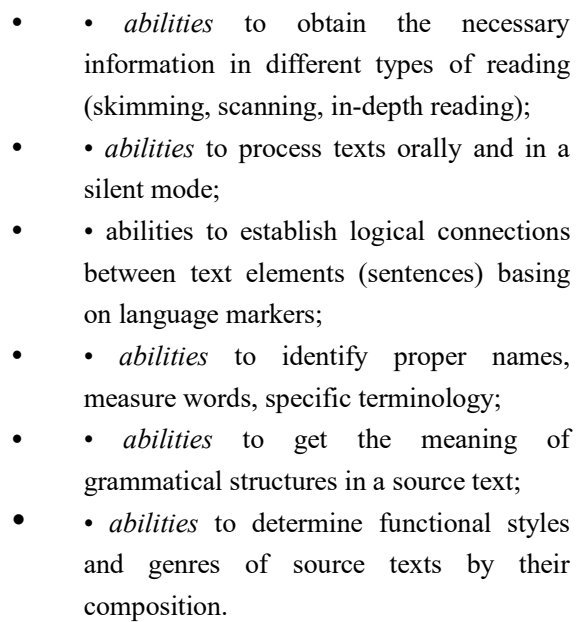 & $\begin{array}{l}\text { - skills to identify units } \\
\text { of analysis in a source } \\
\text { text (semantic segments) } \\
\text { and to correlate them; } \\
\text { - skills to divide text } \\
\text { subjects and predicates } \\
\text { into communicative } \\
\text { quanta and to identify } \\
\text { dominant information in } \\
\text { each of them; } \\
\text { - skills to use effectively } \\
\text { different types and } \\
\text { forms of reading. }\end{array}$ \\
\hline
\end{tabular}

The developed oral skills are proved to facilitate the mastering of interpreting skills, whereas the developed skills in reading and writing contribute to the improvement of translating skills. Some issues regarding the competence-based approach to the training of future translators / interpreters were laid out in our previous work $[10 ; 6]$. So, we have transformed some content positions into the integrated linguistic-and-communicative competence which would be suitable for both future translators / interpreters and teachers of Chinese / English. Let us consider the frameworks of specific skills in reading and writing (see tables 6-7).

We should assume that fluent assimilative reading can serve as a platform for developing and mastering skills in writing. Ukrainian students majoring in Chinese encounter much difficulty decoding hieroglyphs-symbols (similar ones, in particular: e. g. 鸟 niăo / a bird and 马 mă / a horse), on the one hand; and determining their semantics, on the other hand, since homonymy is a wide-spread phenomenon in the Chinese language (e. g. 丁 dìng / an experienced, senior worker and 丁 dīng / Ding, a Chinese surname). Taking the above mentioned facts into consideration, it takes students more time to master Chinese reading skills than English reading skills. Reading skills are referred to the sphere of perception, whereas writing skills - to the sphere of production. Let us get acquainted with the writing skills specifications (see table 7).

We would like to highlight the fact of unrelated linguistic nature between the Chinese and English languages, which impedes parallel assimilation of both languages. An appropriate system of exercises is to be introduced into the teaching / learning process. In this regard, translating / interpreting training activities occupy a leading position in learning foreign language. Therefore, we suggest that translating / interpreting skills should be included into students' foreign language outcomes. The translating / interpreting skills components are presented in table 8.

Table 7. The linguistic and communicative competence in foreign languages (English, Chinese): Writing

\begin{tabular}{|c|c|c|}
\hline Knowledge & Abilities & Skills \\
\hline \multicolumn{3}{|c|}{ Writing } \\
\hline $\begin{array}{l}\text { - knowledge of the composition, lexical } \\
\text { and grammatical framework of academic } \\
\text { documents (professional correspondence, } \\
\text { applications, letters of recommendation, } \\
\text { etc.); profession-related issues } \\
\text { (informative essay, instructions, manuals, } \\
\mathrm{CV} \text {, etc.); scientific papers (articles, } \\
\text { reviews, etc.). }\end{array}$ & $\begin{array}{l}- \text { abilities to generate and } \\
\text { process academic, scientific } \\
\text { and profession-related texts. }\end{array}$ & $\begin{array}{l}\text { - skills to "encode" authentic } \\
\text { information (to write Chinese } \\
\text { hieroglyphs, in particular); } \\
\text { - skills to produce academic, scientific } \\
\text { and profession-related texts, keeping } \\
\text { to the linguistic standards of Chinese / } \\
\text { English and Ukrainian. }\end{array}$ \\
\hline
\end{tabular}


Table 8. The linguistic and communicative competence in foreign languages (English, Chinese): Translating / Interpreting

\begin{tabular}{|c|c|c|}
\hline Knowledge & Abilities & Skills \\
\hline \multicolumn{3}{|c|}{ Translating / Interpreting } \\
\hline $\begin{array}{l}\text { - knowledge of translation } \\
\text { tools (strategies, tactics, } \\
\text { techniques, methods, } \\
\text { models of translation) }\end{array}$ & $\begin{array}{l}\text { - translation / interpretation analysis (all stages } \\
\text { - pre-translating / interpreting, analytical } \\
\text { searching, analysis of translation / } \\
\text { interpretation results); } \\
\text { abilities to overcome multilevel linguistic and } \\
\text { extra-linguistic difficulties in the translation / } \\
\text { interpretation process. }\end{array}$ & $\begin{array}{l}\text { - bilingual skills to switch quickly } \\
\text { from one language to another; } \\
\text { skills to choose adequate translation / } \\
\text { interpretation tools and actions to } \\
\text { reproduce the original text content in } \\
\text { another language. }\end{array}$ \\
\hline
\end{tabular}

We acknowledge the necessity to develop students' creative qualities for their productive professional activity and highlight the ones proposed by A. Matraeva, M. Rybakova, M. Vinichenko, A. Oseev and N. Ljapunova: openness to new experiences, the abilities to elaborate ideas, to predict, to analyse and synthesise, to make decisions, to notice problems and to solve them; propensity for symbolic, associative thinking [8].

The designated criteria contribute to the elaboration of qualification standards for learners of foreign languages (English, Chinese) which should be followed in order to be competitive at the labour market in compliance with the European standards and the Chinese "Belt and Road Initiative" and "A New Silk Road" projects.

\subsection{Teaching Tools}

We can affirm that foreign language immersion environment and profession-oriented speech practicing are the pedagogical conditions which can facilitate mastering a foreign language. For the future teachers and translators / interpreters of Chinese and English these assignments / class activities are appropriate: the lecture-briefing "A teacher or a translator / an interpreter: pros and cons?", the interpretation workshop "Modern techniques in teaching a foreign language", the role playing game "We are proud of our cultural heritage", etc.

The lecture-briefing "A teacher or a translator / an interpreter: pros and cons?" complies with the cooperative learning teaching tool which helps to assist in developing students' skills and abilities to work in teams and to think critically by means of a foreign language. During the lecture-briefing, students - "journalists" - ask the lecturer topical questions on advantages and disadvantages of being a teacher and a translator / an interpreter in English / Chinese; they also demonstrate their presentations and answer the journalists' questions covering specificities of their professions. This kind of lecture is aimed at rousing students' love of their future professions.

The interpretation workshop "Modern techniques in teaching a foreign language" motivates students' self-guided work and align with the method of professional development. The university instructors allocate tasks based on students' skills and abilities on the one hand, and give appropriate support to those who need time and explanation for improving their skills to use encyclopaedic, referential, special literature, English $\leftrightarrow$ Chinese, English $\leftrightarrow$ Ukrainian, Chinese $\leftrightarrow$ Ukrainian dictionaries of various types, software and information technologies to find the necessary profession-oriented material on the other hand.

The role play game "We are proud of our cultural heritage" corresponds to the inquiry-based instructions, a method which presupposes thought-provoking questions related to the background knowledge and facilitates the improvement of students' writing skills (informative essays, instructions, manuals, $\mathrm{CV}$, articles, reviews, etc.). Searching for answers / decisions appears to inspire students to ponder upon culture-centred issues against the background of their native culture, which allows them to become more independent learners.

The above-listed educational corpus has contributed to the improvement of the Ushynsky University students' learning outcomes, practical experience as well as stipulated their mastering of profession-related issues.

To sum up, aspect-targeted training in a foreign language (listening comprehension, speaking, reading and writing combined with translating / interpreting); keeping to local specificities, education requirements and cultural traditions; the need in teachers' advanced training and the correlation of the Ukrainian qualification standards, syllabi and curricula with the European and Oriental ones facilitates students' academic success and teachers' further professional mastery.

\section{Conclusions}

The keynote aspect of the Chinese / English teaching / learning is quality, its continuous improvement. Here are some suggestions in this respect.

- It is necessary to hold regular seminars, conferences and advanced training for Chinese / English teachers, where they can discuss and update the quality assessment criteria, tendencies of the Chinese /English language development and its new teaching methods. 
- It is desirable that each teacher of Chinese / English should attend his / her colleagues' classes (mutual attendance), discuss all gaps in teaching methodology alongside with positive achievements, and share experience.

- We should improve and optimize curricula and syllabi based on the existing education standards.

- The academic cooperation between China, Europe and Ukraine must be strengthened.

- Chinese / English teachers must learn a local language, observe local specificities, requirements and cultural traditions in order to make Chinese / English classes more effective.

- Ukrainian exchange students who study in China and in English-speaking countries should immerse into local (Chinese) customs and traditions.

- While adapting and optimizing education standards, we should meet the professional needs of students, take into consideration their proficiency levels and corresponding study objectives, elaborate profession-oriented methodological support.

- It is expedient to implement aspect-targeted training in Chinese / English into the Translation syllabi alongside with theoretical and practical issues of translating / interpreting, speaking, grammar, listening comprehension, and writing. As for the Chinese / English language and Literature syllabi, it is desirable to focus students on grammar and Chinese / English teaching methods.

- The Chinese / English teachers, together with the local ones, are to adapt the authentic methodological support to the local educational requirements, demands and teaching peculiarities as well as to elaborate new educational materials that meet practical educational needs (both printed and in electronic form).

Summing up, while adapting Chinese / English language education standards and tests, one is to take into consideration multifaceted factors, for example: local educational specificities and language, age of students, teacher's mastery (or lack of mastery), students' proficiency levels and professional needs, study objectives, Chinese / English teachers' desire to do something new at their professional level, etc. This process needs time and mutual tolerance.

The prospect of the study is seen in elaborating unified education standards and methodological support which could meet modern qualification requirements for improving the quality of students' learning outcomes and teachers' proficiency.

\section{REFERENCES}

[1] Arias, M. A. I., García, T. C. S., Dávila, Y. V. C. (2019). La formación por competencias requiere una evaluación autentica en la Universidad. Revista Dilemas Contemporáneos: Educación, Política y Valores (2019), 7, Special Issue. Available at: http://www.dilemascontem poraneoseducacionpoliticayvalores.com [in Spanish].

[2] Common European Framework of Reference for Languages: Learning, Teaching, Assessment. (2001). Strasbourg: Cambridge University Press [in English].

[3] Epstein, R., Runco, M. A. \& Albert, R. S. (Eds.). (2005). Generativity theory and creativity. Theories of creativity (Rev. ed.). Hampton Press, Cresskill, NJ [in English].

[4] Fernández, Daniel Madrid \& Pérez Cañado, Maria Luisa. (2012). CLIL Teacher Training. In book: Teaching and Learning English through Bilingual Education. Cambridge: Cambridge Scholars Publishing, pp.181-212 [in English].

[5] God, Y.T., \& Zhang, H. (2019). Intercultural challenges, intracultural practices: how Chinese and Australian students understand and experience intercultural communication at an Australian university. High Educ (2019), 78, p. 305. Available at: https://doi.org/10.1007/s10734-018-0344-0 [in English].

[6] Korolova, T., \& Popova, O. (2019). Developing Ukrainian Students' Skills in Translating Official Documents from Chinese into English and Ukrainian. Revista Dilemas contemporáneos: Educación, Política y Valores, Year VII, Special Edition (October 2019). Available at:https://dilemascontemporaneoseducacionpoliticayvalore s.com/_files/200006055-bb2c8bb2ca/19.10.13\%20Desarro $110 \% 20 \overline{d e} \% 201$ as $\% 20$ habilidades $\% 20 \mathrm{de} \% 20$ estudiantes $\% 2$ Oucranianos.....pdf [in English].

[7] Lu, X., \& Chen, B. (Eds). (2019). Computational and Corpus Approaches to Chinese Language Learning. Applied Linguistics (Springer, 2019). Available at:https://doi.org/10.1093/applin/amz054 [in English].

[8] Matraeva, A., Rybakova, M., Vinichenko, M., Oseev, A., Ljapunova, N. (2020). Development of Creativity of Students in Higher Educational Institutions: Assessment of Students and Experts. Universal Journal of Educational Research, 8(1), pp. 8-16. DOI: 10.13189/ujer.2020.080102 [in English].

[9] Policy Brief: Enhancing youth employability: The importance of core work skills. 2013. Online available from

http://www.ilo.org/skills/pubs/WCMS_234467/lang--en/in dex.htm [in English].

[10] Popova, O. (2015). Criterial approach to professional and speech training targeted for the future translators of the Chinese language. Scientific Bulletin of South Ukrainian National Pedagogical University named after K. D. Ushynsky, 1(108). (Series: Pedagogy). (pp. 64-68). Odesa: PNPU [in English].

[11] Rychen, S., \& Tiana, A. (2004). Developing Key Competencies in Education: Some Lessons from International and National Experience. Geneve: UNESCO-IBE, Studies in Comparative Education [in English].

[12] Tarnopolsky, O. B. (2018). Principled pragmatism, or well-grounded eclecticism: a new paradigm in teaching English as a foreign language at Ukrainian tertiary schools. Advanced Education, 10, pp. 5-11. Available at: 
https://doi. org/10.20535/2410-8286.133270 [in English].

[13] The Law On Education (2017). Kyiv: Adopted by the Verkhovna Rada. Available at: https://www.ven ice.coe.int/webforms/documents/default.aspx?pdffile $=\mathrm{CD}$ L-REF(2017)047-e [in English].

[14] The Law On Higher Education (2019). Kyiv. Available at: https://zakon.rada.gov.ua/laws/show/1556-18 [in Ukrainian].

[15] Trotsko, A. V., \& Korotkova, Y. M. (2018). Using information and communication technologies in the process of teaching foreign languages: the experience of Ukraine and Greece. Information Technologies and Learning Tools, 6 (Vol. 68), pp. 168-180. Available at:https://journal.iitta.gov.ua/index.php/itlt/article/view/23 40 [in English].

[16] Xiangdong, Li. (2019). Teaching translation and interpreting courses to students' lacks and wants: An exploratory case study of prioritizing instructional objectives. Círculo de Lingüística Aplicada a la Comunicación, pp. 159-192. Available at: http://dx.doi.org/10.5209/CLAC.64377 [in English].

[17] Ying, T., \& Khe, F. H. (2019). Examining the utility and usability of mobile instant messaging in a graduate-level course: A usefulness theoretical perspective. Australasian Journal of Educational Technology, 2019, 35(4), pp. 128-143 [in English].

[18] Zhu, B., Gao, H., Wu, H., \& Wang, W. (2019). Studying crashes to avoid clashes: A translational approach to develop terminological competence for aeronautic communication. Círculo De Lingüística Aplicada a La Comunicación, 79, 119-138. Available at: https://doi.org/10.5209/clac.65651 [in English]. 